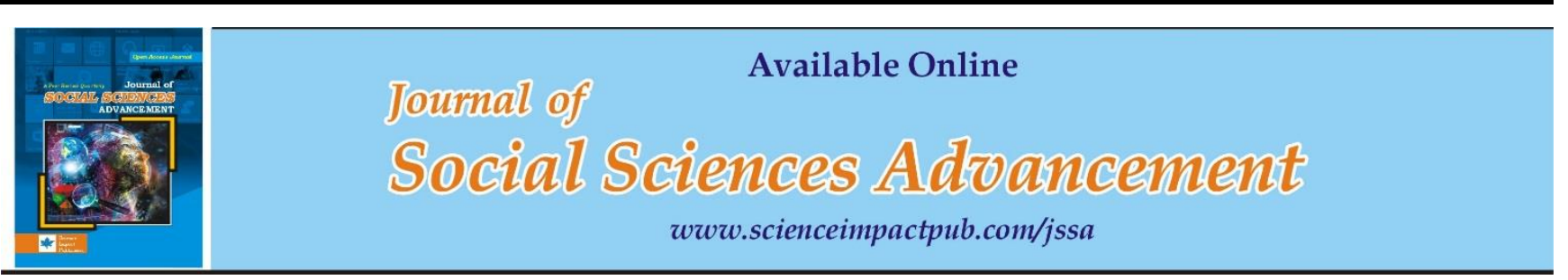

\title{
Digital Documentation of Museum Collections for Sustainable Development
}

\section{Sadiq Lawan ${ }^{1 *}$ and Umar Lawal Yusuf ${ }^{2}$}

1Department of Fine Art, Faculty of Environmental Studies, University of Maiduguri, Nigeria

2Department of Sociology and Anthropology, Faculty of Social Sciences, University of Maiduguri, Nigeria

\begin{abstract}
Digitalization enhances the impact of museum collections, and it is a global trend for sustainable development. Documentation of museum collections is an essential part of museum development because there is no meaningful museum setting without proper documentation. It is through documentation that museum collections would be understood and appreciated by the audience. Initially, documentation of museum collections can be done through manual procedures. Today, with the advent of digital technology, museums are taking another dimension, paradigm shift from analogue to digital. Different cultural organizations have called upon digital documentation of museum collections to sustain the vital information, accessibility and preservation of collections. People can easily access museums online, secure objects, and go in line with sustainable development. The most crucial part of digital documentation is to manage, administer, record keeping and maintenance. Digital museums are drivers of research, education, creativity, employment, entertainment, economic growth and development. Many museums institutions in Africa and other parts of the world are not digitalized. The paper's objectives are to explore digital documentation, its significance, and what digital tools can be used to digitalize museums. The article adopted content analysis, using a secondary source of data. The sources include textbooks, articles in journals, newspapers, pamphlets etc. All these volumes form the data. The paper finds that digital documentation is important in every human endeavour to ascertain sustainable development, easy connectivity with other social development sectors, and protection against illicit trafficking and other crime against museum objects. The paper recommends that museums in Africa should key into digitalization and employ experts to facilitate museum activities professionally.
\end{abstract}

\begin{tabular}{l}
\hline Keywords: Digital; Documentation; Museum; Collection; Development \\
\hline${ }^{*}$ Corresponding Author: Sadiq Lawan, Email: sadiqlawan6@unimaid.edu.ng \\
(C) The Author(s) 2021.
\end{tabular}

\section{INTRODUCTION}

Documentation in museums virtually deals with the compilation of entire information of the objects in an appropriate channel. Documentation means gathering and recording the available information contained in the collection, both in terms of written and visual content. Indeed, through this process, one can understand the cultural value and history of the object in the museum. Documentation enables people to appreciate culture, revive and bring back their lost glory and appreciate information embodied in the objects. Documentation, according to Ezeokeke et al. (2015) asserts that is a process of collecting, recording and storing information relating to an object or a collection of objects.

Hence, digital documentation is an advanced way of collecting, recording and storing available information using an electronic device to carry out the process. It is a new area of discourse. This method enables the act of good preservation, protection of an object when adequately captured information surrounding the objects. The electronic device used in documentation can centralize, store, record and exhibit museum objects that can open opportunities for employment, creativity, education, research, accessibility, well-being and many more. Such activity will enrich museum facilitation and upgrade the standard of collections around the globe. Though, digital documentation became a fundamental activity in the museums due to the integration of digital technology in all ramifications. The process of digitalization enables museum audiences to access information through internet connectivity from their doorstep.

Therefore, in the entire museum unit, neither the work of the education officer, conservator, curator or exhibition officer is capable of not being complete unless the documentation officer plays a significant role in documenting accurate information on the collections. Rupert (2014) posits that without documentation, we can't understand or do anything meaningful with our objects, so we can't use them to do all these inspiring things we pride ourselves in. While Dean et al. (2013) further elaborate that museums can only be of service if they are used. They will be used if people know about them and only if attention is given to interpreting objects in terms that the visitors can un derstand. In this case, the digitalization of museums can widen the scope of the museum and make it relevant to the larger society, and it can be sustainable, suitable for the preservation of the collections and their information. 
Museums are in the position to promote culture, grow the economy, encourage unity and diversity among the people because of the multidimensional nature of their program. Indeed, it is also essential for museums to be flexible in order to go with the present and future generations. Oluwayinka et al. (2014) opined that museums in contemporary societies are expected to be flexible in order for them to be able to implement transformation programs. Such flexibility is required of contemporary organizations that hope to keep pace with the frequently changing needs of those they serve. Nevertheless, that would not be achieved without proper digital documentation, and the duty of a museum is to document and disseminate information to its audience through different means.

Therefore, many cultural organizations worldwide are calling for the digitalization of museums in order to magnify collections in the museums and open a new chapter of transformation. Digital documentation does not only contribute to its relevancy, but rather it's also upgrading its universality. It is against this background that the paper was developed to explore the digital documentation for sustainable development.

\section{Statement of the problem}

There are a series of cultural challenges in the museum across the world due to the fact that natural and cultural objects have been stolen and trafficked to other parts of the world for the market, especially those that are stolen from the Middle East, Asia, Africa and Southern America are taken to Europe and America during the conflict and imperialism. Indeed, people are calling for the repatriation of these artefacts, which some are begun to accept and comply with calls.

There is also the destruction of heritage sites and monuments in some troubled areas across the globe, which, without proper documentation, they can be lost forever. These challenges mostly occur as a result of manmade or natural disasters, and it has become a global phenomenon that many cultural organizations are calling for protection, recovery and measures to avoid further cultural genocide and looting. For instance, if not because of the documentation report, Benin Bronze could not have been traced and restituted to Nigeria by Jesus College Cambridge on October 272021.

Indeed, many cultural organizations like the International Council of Museums (ICOM), United Nations Economic and Scientific Cultural Organization (UNESCO), Museum Security Network, ICCROM, ICOMOS, among others are firmly stand to protect the cultural heritage of the people around the world. Several seminars, workshops and symposiums were organized to commemorate and create networking on the related topic to brainstorm on how to centralize museum institutions and protect its interest. ICOM organizes seminars and workshops for museum personnel; it organizes and coordinates meetings, training programs at the regional, inter-regional and global levels (Burcu G, 2012). Therefore, with the digital documentation of museum collections, recovery, repatriation and protection of the cultural and natural objects would be minimized. There are pieces of literature written on the documentation of museums in very large contain but this paper is more elaborate on the digital documentation of museum collections and their significance which is a new area of concern. This paper is looking at the necessary social network to explore museum documentation and its significance through digital tools.

\section{Objectives of the Study \\ The objectives are to: \\ i. explore digital documentation of museum collections \\ ii. identify digital tools that can be used to the digitalized collection in museums \\ iii. significance of digital documentation}

\section{Research Questions}

The questions of the research are:

i. What is digital documentation?

ii. What are the digital tools that can be used in the digitalization of museums?

iii. What is the significance of digital documentation in the museum?

\section{CONCEPTUALIZATIONS}

Documentation of museum collections can be discussed by different scholars from different perspectives, but for the purpose of this paper, one can easily understand what is museum documentation and its significance in this context of discourse.

Documentation of museum collections does not only contribute to the development of museum objects; rather, it is also adding value and relevancy to the objects. The quality of information of the objects inscribed determines the value, aesthetic, classification and size of the objects within the record book for further understanding. But, in this context, installation information into a digital device that can be easily accessible and appreciable for the audience in the area of concern. Jennifer (2018) defined museum documentation as needful in the sorting, classification and storing away of collections for future use. 
Poole (2013) further inscribes that documentation of a museum is a vital form of record that differentiate a museum from a junk room. The junk room is made of items without proper arrangement and document to support its essentiality, while the museum is a prominent institution that contains collections of natural, cultural and historical value. It is also classified, categorized for easy identification for researchers, students, conservators, exhibition officers and visitors.

However, when collections lack accurate information, it would be difficult for an education officer to interpret the genuine information for museum visitors. Indeed, a missing portion of information leads to misconception and mistrust embodied in the collections, especially for those who are conversant of history. Whenever information is extorted, it would affect various sectors includes research, exhibition and education. Thus, digital documentation in museum prevent endangered culture and helps to preserve their information for future endeavour. Ezeokeke et al. (2015) explain that the documentation allows the museum to manage, understand, interpret and use collections now and in the future.

Indeed, digital documentation provides information and control over intellectual property rights issues, especially in the areas of cultural rights and activities. Documentation stands as a mark of all museum activities and ramifications. Initially, digital documentation was considered contradictory in a museum set up because of the loss of authenticity, originality and security of objects.

However, Borowiecki et al. (2017), Citton (2014) and Citton et al. (2014) further enumerate that museums have enjoyed larger numbers of online visitors benefiting from expert information on museums. These opportunities were accompanied by a series of challenges needed to face, such as a widening range of available entertainment offers to consumers, combined with the shrinking free time and attention could devote to respective leisure activities. Despite that, digital documentation became important in current museum work due to the paradigm shift from analogue to digital technology and museum marketing across the world.

Trilce (2020) posits that museums increasingly connect all the information related to the objects in a repository, including images, history of the object, conservation reports, exhibition texts, related publications, and physical location of the objects. According to Horan, Genevieve A. (2013) explained that the use of digital heritage enables museum users to virtually visit the museum first to learn about the available exhibits, programing programming and collections, and in some instances, curate their own online collections of their favourite art, artefacts and specimens. As the virtual and digital computer domains expand, so does their potential for use by museums institutions.

\section{METHODOLOGY}

The paper adopted the qualitative research method. The qualitative method desires no mathematical summation; table, diagram or graph rather use descriptive content analysis. Burns (2000) posits that qualitative research method is descriptive, presentation and methodological decision on what is best, a hypothesis-free orientation and looking natural scheme of things. The paper solidly relies on a secondary source of data collection. The sources of the data are mainly retrieved from textbooks, articles in journals, newspapers, pamphlets. All these volumes form the data. The reason (s) why the paper adopted content analysis is that most of the literature consulted are limited and lack in-depth analysis on museum documentation but the combination of the manuscript and experiences on the field as developed the paper and rich the discussion on the field of cultural studies.

The findings and discussion of the data were presented and analyzed according to the research objectives, each one of which generated questions and answers. Strauss et al. (1990) explained that the presentation of data begins with the categorization and organization of data in search of patterns, critical themes and meanings that emerge from the data. The researchers presented the data retrieved from the different sources by interpreting in detail and citing the main source of information and critically discussed. The paper utilized both presentations of results and discussion of the data in order to make the reader understand the information clearly.

\section{RESULTS AND DISCUSSION}

\section{Digital Documentation and Tools used in Documenting Collections:}

Digitalization of museums can be done in many ways, using different digital tools to facilitate documentation. Indeed, it is only through documentation that museum collections would be understood and appreciated. Initially, documentation of museum collections can be done through different means, entirely of manual form. Today, with the advancement of information technology, museums are beginning to take another dimension, paradigm shift from manual to digital. Matassa (2011) opined that instead of staff using handwritten or typed information related to 
objects and specimens that were generally organized in some institution-specific filing system, they were able to input this information digitally, creating centralized information that was more easily retrievable.

Seeking digital documentation requires huge investment, especially software documentation, hardware and skilled professionals on digital technology for management. Most organizations like banks, ministries, parastatals, agencies and departments go digital due to the fact that digital technology virtually took over the entire sectors of life.

Trilce (2020) observes that museums can innovate in their organizational form (for example, by hiring new skilled staff or adopting new managerial forms, such as creating a Chief Technology Officer position. Through this development, a museum can magnify its activities and provide a 3D digital scan in documenting images, pictures, antics, artefacts and other valuable objects that would turn museum work more organized, easy to operate and reduce the burden of work. The museum needs to join or create digital platforms or networks that would increase or attract visitors' attention. For instance, active networks like YouTube, Instagram, Facebook, Twitter page, Website, Mobile app and other digital platforms should be encouraged in order to document necessary information of the collections on these digital devices.

$\mathrm{Li}, \mathrm{Yu}-\mathrm{C}$, . (2015) affirm that digital museum implementations such as museum websites and mobile apps have been used to replace the concrete building and its function. However, we are living in a world where the fast growth of technology and the Internet have raised the expectation about the function of digital museums compared to a decade ago. Navarrete, T. \& Mackenzie O, J, (2011) cited in Marty \& Burton (2008) make a distinction between objects that can be linked to information along a scale of raw data basic facts, i.e. size, name, origin, materials, image, refined data (e.g. keywords, classification codes, tags), and mediated information (narrative or interpretative text). Indeed, digitization projects have mainly focused on the raw data and left museum objects in digital databases and metadata with only partial keywords and a glaring lack of mediated information.

Horan, Genevieve A., (2013) (in U.S. National Archives, 2008) further observes that metadata is an important factor of digitization, which is "the act of scanning [or photographing] analogue documents into digital form, that results in a digital copy being made available to users via the Internet or other means for a sustained length of time," as it allows for the user to gain pertinent information about digitized images and accompanying information.

Museums need to develop information management units or databases to restore their digital collections on the Internet for demands, security and accessibility. Thus, it would cost a lot, time-consuming, but it could help museums to expand and disseminate information quickly. Furthermore, many museums across the globe often lack a specific digital budget plan to partake in this digital process. However, that would be a challenge of digital documentation in museums development, and it would affect sustainable development. The finance of museums could be traced to many sources despite the fact that the not-profitable nature of the institutions and museums could afford to digitalize her museums when professionally explored opportunities at its disposal.

The only way and manner in which museums reach out to people and touch the life of museum admirers in present and future are through digital documentation and presentation. Therefore, without the integration of digital technology in keeping records of museum collections in the near future, museums decline from global space, and their relativity would be at stake. Museums are the memory of humankind, which contributes significantly to the national and international development by every intent and purpose, is a root of the culture and tradition of every living creature on the faces of the earth (Binkat, 2014).

The link between the present and next generation in museums are the accurate object's documentation through different digital tools. Audio-visual/ Gallery backup; in its broadest, the term concerned with seeing and hearing simultaneously. This has to do with having a voice in the background of the museum set up or galleries to help attract, explain, exhibit and display some collections digitally to captivate the target audience mind to demand more such. It also helps to sustain museum admirers' attention and restore information. This would greatly help in capturing young folks who are easily manipulated by the museum activities in such a way that a huge number would be able to move into the museum environment.

Slide show projector; the museums must embark on using media houses to inform the public of certain outdoor film shows using things like the slide show projector to display some events. In launching out, museums can penetrate even to rural areas and televised captivating films. This would encourage the public to come to the museum where they can see more collections be it in mobile museums or permanent museums. Digital photographs/Film show; it is obvious that this program involves displaying moving pictures of interest and videos in galleries that would help to explain certain exhibits, for instance, historical events like the slave trade, colonization, documentaries, distinct tribal festivals, activities of jihadist and what have you. Other important aspects of museum documentation are digital screen advertisement. This milestone development for the museum to display its program on the digital street screen to showcase its daily program for people to see, the museum would become so attractive to the people by creating 
the screen show relationship between the museum and the people. It would help the museum to become well known around the society and its people.

Therefore, these developments cannot be achieved without digital documentation and presentation of museum collections and through this process, museums can be of help in all ramifications of human endeavours and curtail societal challenges through available means. For instance, issues of environmental sustainability, social and economic development can be addressed in museum institutions using the pragmatic method of disseminating information to its audience.

Indeed, society needs to adopt a different method in creating awareness and enlightening people in public space through the practical method. So that people would realize the danger involves either on the natural environment or social space. For instance, a movie titled "Blood Diamond" acted by Leonardo DiCaprio, exhibited the real character of exploitation, conspiracy and instability in Liberia. Though, those who watched the movie realize the danger involved in economic crisis. Indeed, museums serve as memory reminding and rebranding people to be proactive, diligent and educate them to understand their natural environment.

\section{SIGNIFICANCE OF DIGITAL DOCUMENTATION}

Digital documentation is a method of processing, organizing, presenting, storing information in a digital device for the benefit of a target audience. Elom et al. (2019) explain that digitization is crucially important to data processing, storage and transmission because it allows information of all kinds to be carried with efficiency and to be integrated. Nevertheless, the Network of European Museum Reports on Digitalization (2021) critically observes that digitalization offers museums numerous opportunities. It not only make exhibits accessible to everyone, but it also addresses the lack of physical space to display all objects in the museum possession. For instance, during Covid-19 lockdown most of the digital museums continue to connect with their audience through a different digital platform. While those museums that are not digitally utilized are remain close and disconnected from the larger populace.

This development cannot be actualized without digital documentation exercises done by professionals. It is through these initiatives museums played a role in bringing people together to share ideas and give room for virtual communication. Digitalization of museums is very important because every single step in documentation has its own significance and consequences if not done properly. Indeed, it is a means of keeping records; apart from keeping records, it would be a gateway for museum exhibitions that give meaning to collections. It would enable the museum to communicate with its potential consumers and help to educate people of their natural environment, cultural and scientific understanding of diverse institutions.

Navarrete et al. (2011) explain that digitization would further solve the concern of defining where the collections are to be managed, by the museum, reducing the problem of the artificial division of collections, e.g. Rembrandt etchings issued as print as distinct from those issued in books. Digital documentation of museums means the preservation and sustainability of culture. In this case, vital information needed in future can easily get through installing digital records. It is through digital documentation that one can identify objects that belong to which part of the world where and when. It makes people trace objects easily in museums, provides easy access, facilitates objects interpretation and description, provides information and intellectual rights, object preservation, conservation, security and accountability.

However, museum documentation is classified into two fields, and in-house documentation embodied vital information includes name, location, size, history, inscription, tag, classification and category etc. Furthermore, documentation help in insurance evaluation, recovery, deaccessioning and enabling information to move faster than objects. As Okpoko (2011) enumerates, that which is preserved and transmitted is in turn enriched by succeeding generations, thus the unalterable and reliable information. Indeed, digital documentation would open up a new area of action through which museums can succeed, sustain and preserve their information for the benefit of the present and the next generation to come.

Accurate digital documentation can easily attract tourists and boost the economic development of the states. According to Bhatia \& Tripathi (2016), enumerates that tourism has been predicted to be the most important sector of the world economy in the $21^{\text {st }}$ century. For instance, in 2015 alone, there were 800 million international tourist arrivals in the whole world. However, this development creates employment and improve other sectors of the economy. It would further employ both skilled and unskilled labour irrespective of gender or ethnic group. Digital documentation enables people to identify and trace stolen or looting objects easily due to the fact that one can access collections across the globe using different digital tools. 
Azuwueze (2018) explains that illicit trafficking and trading of art materials were also witnessed, especially those that are in the habit of stealing, looting or faking these materials for their own benefit. These activities can be reduced through digital documentation processes and the centralization of objects. Furthermore, digital documentation played a role in the research, education and entertainment sectors. Abungu (2000) posits that development of the society is the main goal of museum documentation. Indeed, education and research is the key area of concern because, according to ICOM (2007), the museum as a non-profit, permanent institution, in the service of society and its development, open to the public, which acquires, conserves, researches, communicates and exhibits the tangible and intangible heritage of humanity for the purpose of education, study and entertainment. The museum objects spoke about themselves and their provenance through description documents and interpreted by the education officer. Information is planned in museums towards educating people.

\section{RECOMMENDATION}

Looking at the digital documentation of museum collection, its tools and significance. The paper recommends that museums in Africa and other un-digitalized museums across the globe should key into digitalization methods in museums in order to ascertain sustainable development. Museums should employ experts to manage accurate information that is kept to avoid distortion, misinformation, mistrust, linkage in the museum. Indeed, it is good to facilitate museum activities professionally due to the fact that digitalization is too expensive to be handled by unprofessional fellows. Many museums have been handled by unskilled, inexperienced and unpassionate staff, but with the upgrade and reintegration, one can see transformation in the museum through digital means. Finally, the museum's centralization through digital documentation needs to be generalized to adherent universality in the museum institution.

\section{REFERENCES}

Azuwueze, G,. A. (2018). An Introduction to Museology: Historical Development of Museum. MATKOL Press. ISBN: 978-166-876-8

Abugun, H.O (2000). Opening up New Frontier; Museum of the 21 century in a museum. Confirmation or Challenge, Sweden. ICOM

Bhatia, M,. \& Tripathi, S,. (2016). Does High Level of Tourism Activities Lead to Higher Level of Economic Development? Evidence from Asian Countries. IJABER, Vol. 14, (2016):2615-2626.

Burns, R,. (2000). Quantity and Quality in Social Research. London, Published by Routledge in March, 2000.

Burcu G.. (2012). Museum Concept from Past to Present and Importance of Museums as Centres of Art Education. International Conference on New Horizons in Education INTE2012. Available online at www.sciencedirect.com

Binkat J. (2014). Museum Documentation, lecture note. Institute of Archaeology and Museum Studies, Jos; Nigeria.

Borowiecki, K. J., Navarrete, T. (2017). Digitization of heritage collections as indicator of innovation. Economics of Innovation and New Technology, 26 (3): 227-246. DOI:10.1080/ 10438599.2016.1164488.

Citton, Y. (2014). Pour une écologie de l'attention. Paris: Le Seuil.

Citton, Y., Crary, J. (2014). L'économie de l'attention: nouvel horizon du capitalisme? Paris: La Découverte.

Dean, D., \& Gary, E. (2013). Handbook for Museum. Rout Ledge Copy Documentation; France, Paris, the International.

Ezeokeke C., N. \& Nwosu C, A, (2015). National Commission for Monuments (ICMM)-Portrait of Leadership, Nigeria (1979-2015).

Rupert, S., (2014). International Council of Museum (ICOM), 1990: ICOM Statue; C.O.E of ICOM Code of Ethics for Museum, ICOM, 2006

International Council of Museum. ICOM Statutes (2007). Austria. Retrieved from http://icom.museum/who-weare/the-organisation/icom-statutes.html\#2

Poole, N, (2013). Museum Documentation: Today and Tomorrow. Nigeria Press Ltd

Jennifer, B, M. (2018). Documentation in Museum Settings; Meaning and Scope. Matkol Press, Nigeria, ISBN; 078-978166-968-9

Trilce, N,. (2020). Digitalization of Museum. Teaching in Cultural Economics. Publishing Guides to Teaching Chapter 27 Digitization in Museums (pp. 204-213). DOI:10.4337/9781788970747.00038. Retrieved from: https://www.researchgate.net/publication/339733610 on November 8, 2021.

Okpoko, A.I (2011). Fundamentals of Museum Practice. University of Nsukka

Network of European Museum (2021). Final Report on Digitization and I.P.R. in European Museums. Prepared by the Network of European Museums with the Support of Nina Szogs. Co-founded by Creative Europe Program of the E.U.

Elom C, M,. \& Adesoji A, O,. (2019). Impact of Digitization on the Teaching and Learning of Chemistry and Mathematics at the Distance Learning Institute of the University of Lagos. Makerere Journal of Higher Education ISSN: 18166822; DOI:http://dx.doi.org/10.4314/majohe.v10i2.11 
Navarrete, T. \& Mackenzie O, J,. (2011). Museum Libraries: How Digitization Can Enhance the Value of the Museum. Palabra Clave (La Plata), vol. 1, no 1, p. 12-20. E-ISSN: 1853-9912

Li, Yu-C,. (2015). Digitization of Museum and Art Gallery: A Framework for Enhancing User Interactivity and Personalization in On-site Environments. Thesis (PhD Doctorate) submitted to the School of Information and Communication Technology, Australia. Retrieved from http://hdl.handle.net/10072/367886 on November 8, 2021.

Horan, Genevieve A.,(2013). "Digital Heritage: Digitization of Museum and Archival Collections". Research Papers. Paper 374.Retrived from http://opensiuc.lib.siu.edu/gs_rp/374 on November 8, 2021.

Matassa, F,. (2011). Museum Collections Management. London: Facet Publishing.

Marty, P, F, \& Burton, K, J.. (2008). Museum Informatics; People, information and Technology in Museums. Published December 31, 2008 by Routledge 356 pages $37 \mathrm{~B} / \mathrm{W}$ illustration.

Oluwayinka, S,. Samuel, C. A. U, \& Emmanuel L. A, (2014). Towards a user Based Perfective to the Transformation of Museums. 8-10 September 2014- Istanbul, Turkey Proceedings of SOCIOINT14- International Conference on Social Sciences and Humanities Paper.

Strauss, C, \& Mouton, J,. (1990). Understanding Social Research; Pretoria. JT Van Schaik

Publisher's note: Science Impact Publishers remain neutral with regard to jurisdictional claims in published maps and institutional affiliations.

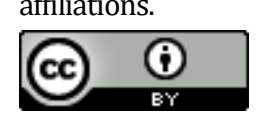

Open Access This article is licensed under a Creative Commons Attribution 4.0 International License, which permits use, sharing, adaptation, distribution and reproduction in any medium or format, as long as you give appropriate credit to the original author(s) and the source, provide a link to the Creative Commons license and indicate if changes were made. The images or other third-party material in this article are included in the article's Creative Commons license, unless indicated otherwise in a credit line to the material. If material is not included in the article's Creative Commons license and your intended use is not permitted by statutory regulation or exceeds the permitted use, you will need to obtain permission directly from the copyright holder. To view a copy of this license, visit https://creativecommons.org/licenses/by/4.0/.

(C) The Author(s) 2021 